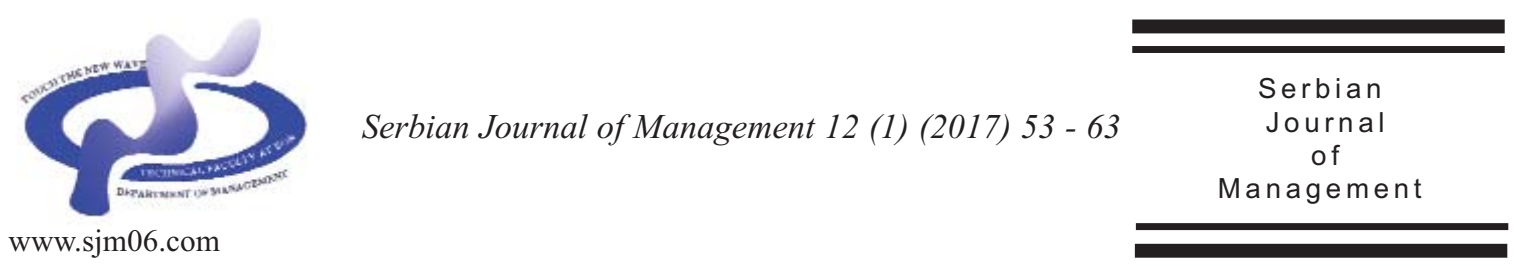

\title{
INFLUENCE OF STRATEGIES TO DETERMINE THE SIGNIFICANCE OF THE CRISIS BY THE MANAGERS OF SMALL AND MEDIUM-SIZED ENTERPRISES
}

\author{
Jaroslav Vrchota* and Petr Rehor \\ University of South Bohemia in Česke Budějovice, \\ Studentska 13, Česke Budějovice, Czech Republic
}

(Received 14 June 2016; accepted 08 September 2016)

\begin{abstract}
Small and medium-sized enterprises play an important role in the European economy as a source of entrepreneurial skills, innovation and employment. Strategic management is vital for long-term competitiveness of these organizations, and even more significant when struggling with a crisis. Enterprises with strategic management are able to look into their future and their managers are able to recognize upcoming issues in advance so they are much better prepared for them. Crisis is then perceived as a phenomenon which is more common than rare. It is therefore essential that businesses reflect the aspects and impacts of the crisis in a corporate strategy and managers learn to manage crises effectively.

The article deals with a partial research of the management of small and medium-sized enterprises in the Czech Republic. It is focused on defining a strategy by the managers of these organizations and the assessment of the significance of crises. Only about $25 \%$ of the companies formulated a strategy for the future direction of the organization. The crises happen in all organizations, varying in degrees and intensity. The importance of crisis is evaluated by the managers by an average rate of 3.4 (where the highest rate was five). The aim of the article is an assessment of the importance of crisis as seen by the managers in strategically managed organizations structured according to sectors of the economy. For primary data collection, the questionnaire method was used.
\end{abstract}

Keywords: strategy, crises, management, small and medium-sized enterprises, sectors of the national economy.

\footnotetext{
* Corresponding author:vrchota@ef.jcu.cz
}

DOI: 10.5937/sjm12-11138 
54

\section{INTRODUCTION}

Small and medium-sized enterprises (SMEs) play a significant part in economic activity through employment, innovation and growth (Floyd \& McManus, 2005), acting as a supplier of goods and services to large organization and any lack of product quality could adversely affect the competitive ability of the larger organizations (Deros et al., 2006). In the European Union, SMEs account for 99.8 per cent of companies, generate 60 per cent of GDP and employ 70 per cent of private sector workers (European Commission, 2008).

In the Czech Republic, the share of SMEs in the total number of active enterprises in 2014 was $99.84 \%$. The share of employees of small and medium enterprises in the total number of employees in the business sector in the Czech Republic in 2014 amounted to 59.39\% (MPO, 2016). At present time, as environment for conducting business and for private enterprise is highly competitive and since external and internal conditions for managing and economising change dynamically, it is crucial that every company has clearly defined conception of their future. They define this conception by clear and proper strategy (̌̌ehoř, 2013).

The field of strategic management is largely concerned with how firms generate and sustain competitive advantage (Ambrosini \& Bowman, 2009). Strategy has been defined by Johnson and Scholes (1993) as the direction and scope of an organisation over the long term: ideally, which matches its resources to its changing environment, and in particular, its markets, customers or clients to meet stakeholder expectations. Strategy is an organizing process that involves both formulation and implementation (Porter, 1996). Strategy is the pattern of decisions in a company that determines and reveals its objectives, purposes, or goals, produces the principal policies and plans for achieving those goals (Andrews, 1971, Freeman, 2010). Strategy is about how an organization sets about getting to where it wants to get (Thompson \& Martin, 2010).

Any entity, a company or municipality, should constantly try to improve itself (̌̌ehoř, 2015). Aims of development, created and realized, within strategic management bring comparative effect (Lednickz̧, 2006) or competitive advantage to organizations (Vodáček \& Vodáčková, 2009). Developing organisational strategy can help organisations and destination to avoid or limit the severity of rapid change induced by crises or disasters (Ritchie, 2004).

Faulkner (2001) notes an increasing number of disasters and crises which affect the tourism industry, ranging from natural to human influenced incidents. Crisis management and organisational continuity are important competencies for managers in both the public and private sector (Lee \& Harrald, 1999).

A number of techniques have been identified by researchers and practitioners to help in the proactive planning and strategy development for the prevention or reduction of crises and disasters through sensing potential problems (Gonzales-Herrero \& Pratt, 1998, Kash and Darling (1998).

There are the main influences which determine the strategy and style of management to to problřm of crisis (Booth, 2015). A number of authors have attempted to define a crisis to help improve their understanding of this phenomenon.

Rais (2007) defines the crisis as such a stage in the life of an organization with a 
negative development of its productive potential and decline in sales for a long period of time. Fialovõ \& Fiala (2006) define the crisis as accumulation of negative influences that make the proper functioning in the area impossible, calling for problemsolving approaches. Generally speaking, the crisis it described as a decisive moment. This is the time when the organization develops adverse performance and unless the situation is resolved in time; its existence is at risk (Řehoř, 2016).

The ability of business owners/managers to think strategically in the midst of a crisis is a key factor in an organisation's long-term survival, but at present there is very little advice available on how to do this most effectively (Vargo \& Seville, 2011). Some managers shine during a major crisis, while others don't. As a strategic manager, one must follow a comprehensive protocol that includes the implementation of teams, systems and tools to respond to a crisis (Springer, 2008).

\section{RESEARCH}

This article aims to assess the impact of a strategy if an organisation to the importance of the crisis, as seen by the managers in SMEs in the Czech Republic. A partial objective is to evaluate the relation between the importance of crises and a defined strategy within the sectors of the national economy as classified by OECD (2014):

Al Industry: High and Medium High Technology;

A2 Industry: Medium Low and Low Technology;

$B 1$ Knowledge-intensive market services;

$B 2$ Less knowledge-intensive market services;
$C$ Agriculture, construction and utilities.

The data were collected from 183 companies in the Czech Republic in 2014. Research sample was selected using nonprobable random selection, with regard to circumstances of the data collection. The data necessary for conducting the research were collected by a questionnaire survey and they were supplemented by qualitative data, obtained through in-depth interviews as well as case studies.

Representatives of different companies responded to questions concerning mainly crises that they had to solve during their operation on the market. Each of the selected companies identified at least 3 crises they had to deal with trying to minimize the impact on their business activities. Crises that were defined this way were consequently divided into 19 categories. The total number of crisis occurrence was 753 .

Data were tested using two-sample Wilcoxon test and his asymptotic variant. This test is a non-parametrical two-sample test, which is most frequently used, when the condition of data normality is not met.

Let $X_{1}, \ldots, X_{n}$ and $Y_{1}, \ldots, Y_{m}$ be two independent random samples from two continuous distributions, whose distribution functions can only differ in displacement. $\mathrm{x}_{0.50}, \mathrm{y}_{0.50}$ states for the median of the first and second distribution. The hypothesis that the distribution functions of the two distributions are the same is always tested, in other words, the medians are tested for equality. The result of test is compared to the alternative hypothesis (the first of medians $\mathrm{x}_{0.50}$ of companies which have strategies, is greater than the latter) (Freund \& Wilson et al. 2010; Friedrich \& Majovská 2010): $\mathrm{H}_{0}=\mathrm{x}_{0.50}-\mathrm{y}_{0.50}=0$ versus $\mathrm{H}_{\mathrm{A}}=\mathrm{x}_{0.50}>$ $\mathrm{y}_{0.50}$ (Budíková \& Králová et al., 2010). 
In the first stage, all $(n+m)$ values $X_{1}, \ldots$, $\mathrm{X}_{\mathrm{n}}$ and $\mathrm{Y}_{1}, \ldots, \mathrm{Ym}$ are arranged in ascending order by size. The entire process takes place electronically using test statistics software and this step is not described in the article, because it is a lapidary operation. Furthermore, the totals of orders $X_{1}, \ldots, X_{n}$ are identified and stated as $T_{1}$. The sum of the values in the order of companies which do not have strategy $\mathrm{Y}_{1}, \ldots, \mathrm{Y}_{\mathrm{m}}$ will be stated as $\mathrm{T}_{2}$. The next step was to calculate the test statistics for $U_{1}$ and $U_{2}$, while applies that $\mathrm{U}_{1}+\mathrm{U}_{2}=\mathrm{mn}$ (Friedrich \& Majovská 2010):

$\mathrm{U}_{1}=\mathrm{mn} \frac{\mathrm{n}(\mathrm{n}+1)}{2}-\mathrm{T}_{1}, \quad \mathrm{U}_{2}=\mathrm{mn} \frac{\mathrm{m}(\mathrm{m}+1)}{2}-\mathrm{T}_{2}(1)$

If statistics $\min \left\{\mathrm{U}_{1}, \mathrm{U}_{2}\right\} \geq$ tabulated critical value, for the selected ranges of both selections and chosen level of significance, then than we may reject the null hypothesis of the identity of the compared groups on the significance level $\alpha=0.05$.

Since for both samples in all test cases applies that $n, m$ are greater than 30 the asymptotic variant of the Wilcoxon test (Mann-Whitney test) is undertaken, which is used for $\mathrm{n}$ and $\mathrm{m}$ higher than thirty (Budíková \& Králová et al., 2010):

$$
\mathrm{U}_{0} \frac{\mathrm{U}_{1}^{\prime}-\frac{\mathrm{mn}}{2}}{\sqrt{\frac{\mathrm{mn}(\mathrm{m}+\mathrm{n}+1)}{12}}}
$$

Critical codomain for right-side alternative id $\mathrm{W}=\left\langle\mathrm{K}_{2}, \mathrm{n}\right\rangle$. Non-negative values $\mathrm{k}_{1}$ a $\mathrm{k}_{2}$ are strictly defined in critical literature. $\mathrm{H}_{0}$ is rejected on the level of significance $\alpha$, if $\mathrm{U}_{0} \in \mathrm{W}$ (Freund, Wilson et al. 2010).

\section{RESULTS AND DISCUSSION}

Strategic management formulates the principles for the functioning of the entire organization and defines the long-term priorities, direction and areas that the managers should deal with. Using strategies, they determine the way the corporate objectives are achieved. Properly set strategies are vital for success and competitiveness of SMEs. According to survey results, only $1 / 4$ from a total of 183 organizations formulated their strategy in writing (see Table 1). The organizations managed this way can adapt to changes in the environment. They also can flexibly change its strategy and fight against potential crises. Unfortunately, almost 3/4 of SME managers in the Czech Republic are not yet able to look further into the future to prepare for future crises. The companies without an established strategic management lack the ability to see and manage their distant future actively.

Two-sample Wilcoxon test (MannWhitney $U$ test) at the level of importance of $\alpha=0.05$, was used to test the $\mathrm{H}_{0}$ hypothesis $\mathrm{H}_{0}=\mathrm{x}_{0.50}-\mathrm{y}_{0.50}=0$ supposing that the importance of crises is the same in both groups and the $\mathrm{H}_{\mathrm{A}}=\mathrm{x}_{0.50}>\mathrm{y}_{0.50}$ supposing that the crises in organizations without a strategy are more important. For both hypotheses, X stands for organizations with a strategy and $\mathrm{Y}$ stands for organizations without strategy.

The $\mathrm{p}$-value is, according to Table 2, equal to 0.4769 . Considering that the $\alpha$ valie is 0.05 , than the considion that $p$-value $>\alpha$ is evident. Accordingly, the final $\mathrm{p}$-value is greater than the $\alpha$, meaning that the null hypothesis should not be rejected. 
Table 1. Strategy formulation in SMEs in the Czech Republic

\begin{tabular}{lcc}
\hline Strategy & $\mathrm{n}$ & $\%$ \\
\hline NO & 137 & 74.9 \\
YES & 46 & 25.1 \\
Total & 183 & 100 \\
\hline
\end{tabular}

The results are reported in the box-plots in Figure 1. They reported that both groups of enterprises see crises as the same important. Medians of both groups are at 3.4 points. The level of the middle quintile is also the same, ranging from 3.0 to 4.0 points. Enterprises without strategic management differ only in the wider range of values at the level ranging from 1.4 points to 5.0 points.

After that, the sample was divided into five groups based on the OECD classification. The groups were tested by the same statistical method as the whole sample of 183 enterprises. Hypotheses were identical, and the resulting data is shown in Table 3.

As Table 3 revealed, $p$-value is close to zero in one case only - for B1 group
(0.0068). Here, due to a positive value of $\mathrm{Z}$ (2.7059) it can be said that the enterprise with a strategy evaluated a crisis more significantly, compared to the enterprises that do not have a strategy. In all other cases, it was not possible to reject the null hypothesis $\mathrm{H}_{0}$, as in the main sample. However, a particular relation can also be assumed in other categories, as shown in the following box-plots.

The left side of Figure 2 shows A1 enterprises. The figure reveals that the enterprises with strategies have a wider range of values, ranging between the minimum of 1.4 points and the maximum of 4.4 points. The median quantile ranges from 3.0 to 3.4 points. Just as the median which is at 3.0 points, which is similar for the enterprises that do not use a strategy, at the level of 3.2 points. It is interesting that companies without a strategy in this sector do not assess the importance of the crisis under 2.6 points, as seen from the right side of Figure 2.

The right box-plot shows the values of A2 enterprises. Both groups' minimums and

Table 2. Mann-Whitney U test for the sample SMEs

\begin{tabular}{lccccr}
\hline & Strategicly managed & Non-strategicly managed & $\mathrm{U}$ & $\mathrm{Z}$ & $\mathrm{p}$-value \\
\hline $\begin{array}{l}\text { Importance of } \\
\text { crises }\end{array}$ & 4360 & 12476 & 2885 & 0.7113 & 0.4769 \\
\hline
\end{tabular}

Table 3. Mann-Whitney $U$ test for five group based on the OECD classification

\begin{tabular}{llllll}
\hline OECD & $\begin{array}{l}\text { Strategicly } \\
\text { managed }\end{array}$ & $\begin{array}{l}\text { Non-strategicly } \\
\text { managed }\end{array}$ & $\mathrm{U}$ & $\mathrm{Z}$ & $\mathrm{p}$-value \\
\hline $\mathrm{A} 1$ & 66.5 & 53.5 & 21.5 & -0.5893 & 0.5557 \\
$\mathrm{~A} 2$ & 180.5 & 284.5 & 74.5 & 1.0998 & 0.2713 \\
$\mathrm{~B} 1$ & 296 & 694 & 64 & 2.7059 & 0.0068 \\
$\mathrm{~B} 2$ & 314 & 1516 & 236 & -0.9517 & 0.3412 \\
$\mathrm{C}$ & 87 & 508 & 72 & 0 & 1 \\
\hline
\end{tabular}




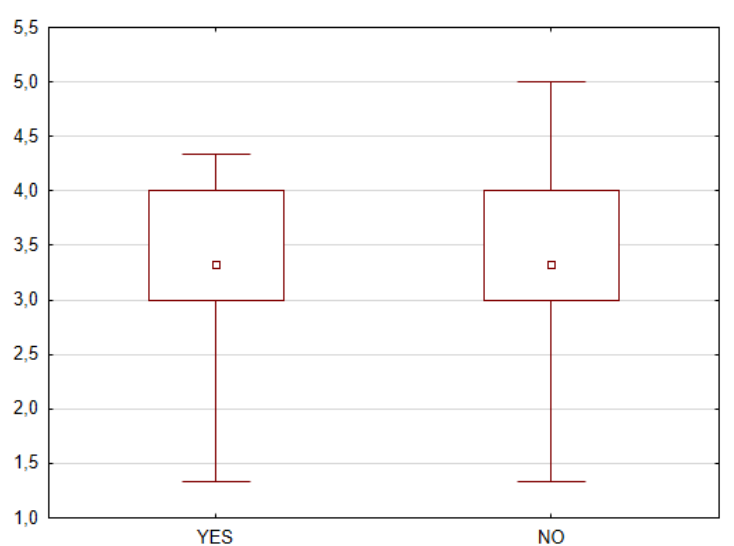

Figure 1. Importance of crises

maximums are the same -1.4 and 4.4 points. The median of strategically run enterprises levelled 3.5 points compared to the median of enterprise without strategic management of 3.0 points. It could suggest that crises are of minor importance for the enterprises without strategic management, but the Wilcoxon test did not confirm this.

As the left side of Figure 3 shows, there is a significant difference between enterprises using strategic management and those without the strategic management in the sector of B1. The enterprises with strategies reported the median value of 3.7 points, the highest level in all sectors. To compare, see the enterprises without a strategy, where the median is at 3.0 points. It is interesting that the variance value is only between 3.0 to 4.4 as the minimum and the maximum. On the other hand, there is a wide variance in nonstrategic enterprises. Also, the mean values of $25 \%-75 \%$ of the enterprises with strategies ranged between 3.4 to 4.0 compared to greater freedom of enterprise without a strategy with the median quantile from 2.0 to 3.4. Graphically, it was managed to confirm the Wilcoxon test, as the p-value was close to zero.

The right side of Figure 3 shows the values of sector B2. There are significant differences between the two groups of enterprises. The enterprises with strategic management reported the median value of 3.5 points, while the median of enterprises without strategic management is 0.2 percentage points higher. Businesses without a strategy reported a wider range of meaning with the responses ranging from 1.4 points to 4.7 , but with a smaller median quintile from 3.0 points to 4.0 points.

Figure 4 shows the enterprises of group $\mathrm{C}$.

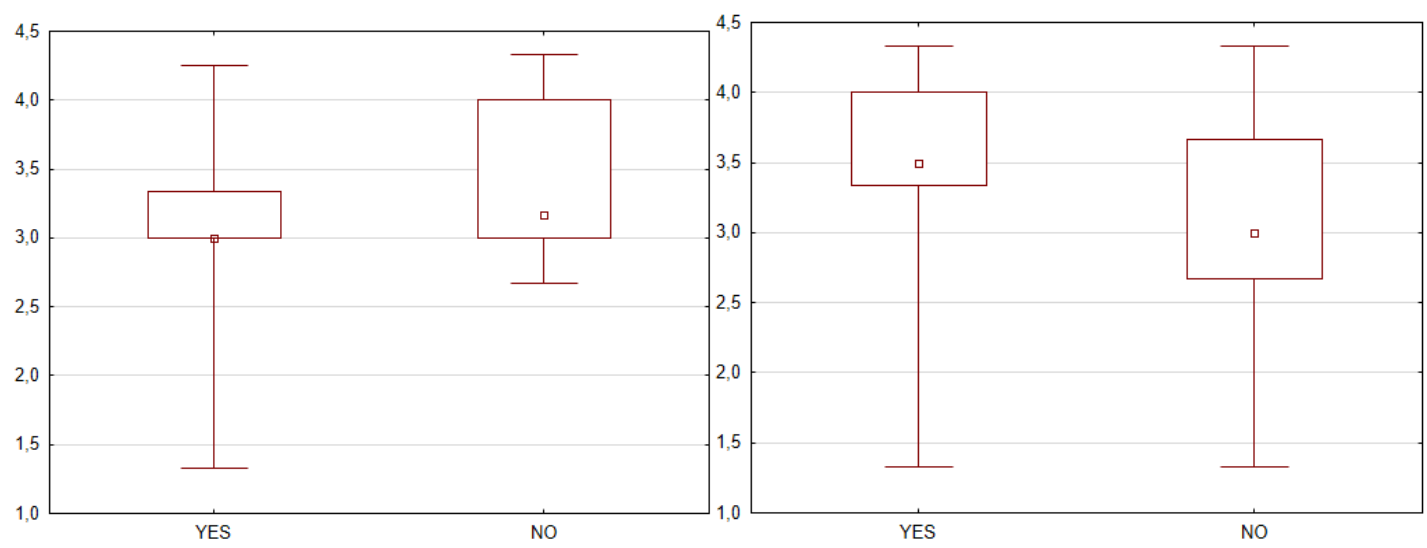

Figure 2. Median and interval of data layout in strategy and no-strategy managed companies from sector A1 (left) and A2 (right) 

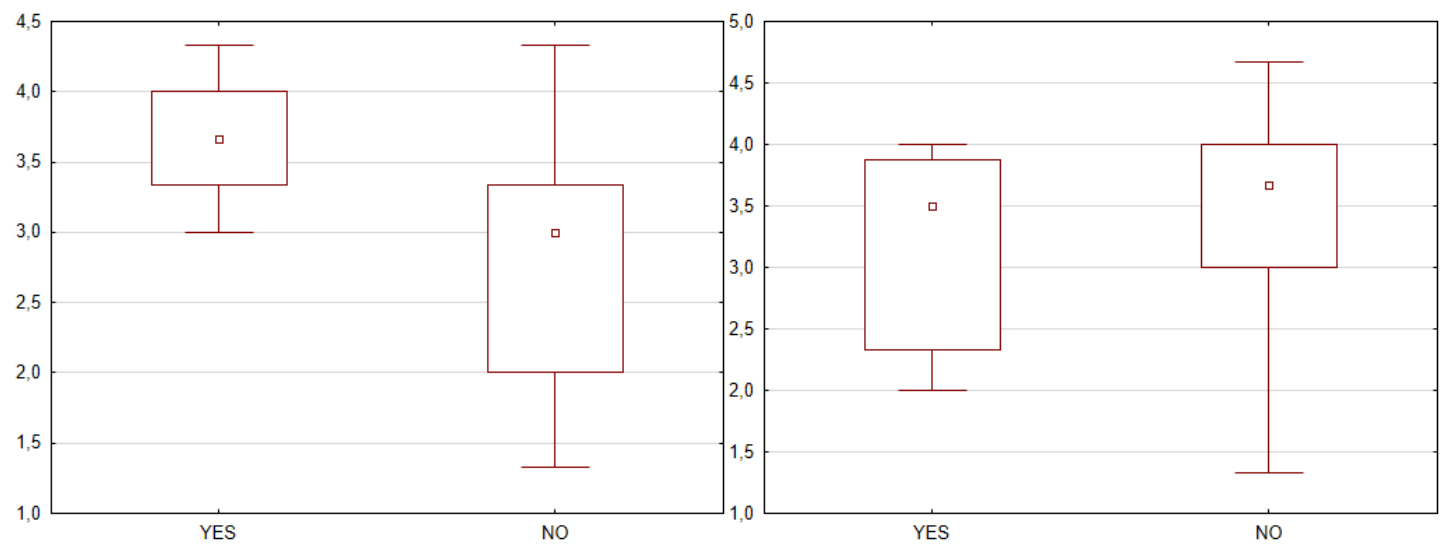

Figure 3. Median and interval of data layout in strategy and no-strategy managed companies from sector B1 (left) and B2 (right)

It is interesting that both groups of enterprises reported a similar level of the median value of 3.4 points, and the minimum value of 1.4 points. The enterprises without strategic management reported greater maximum values at 5.0 points, which is the maximum value for all the sectors, but the middle quantile ranges from 3.0 to 3.5 points. Similarly, $25 \%-75 \%$ of strategically managed enterprises reported the values at the level of 3.0 to 4.0 points.

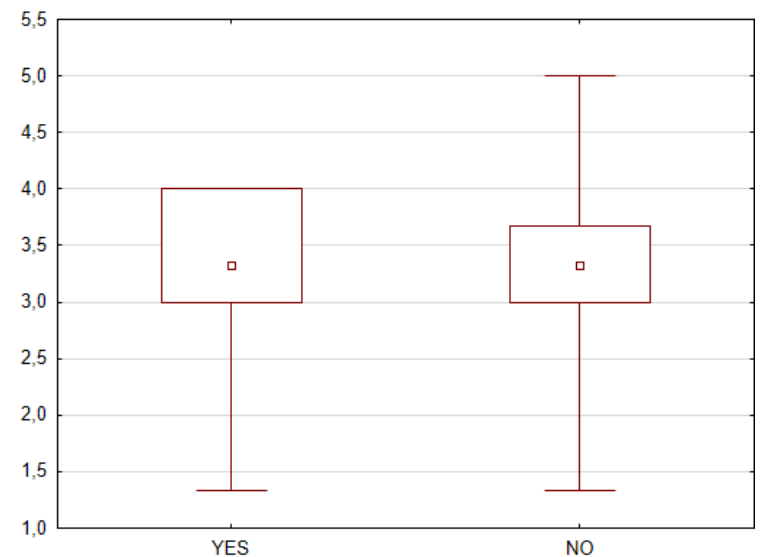

Figure 4. Median and interval of data layout in strategy and no-strategy managed companies from sector $C$

\section{CONCLUSION}

A successful manager of a SME must have a vision of the future development of their enterprise; preferably a written strategy. As a part of the control system, the managers must be able to formulate their strategy, implement it effectively, and change it if necessary. In the Czech Republic, however, 1/5 of SMEs only has a written strategy. All SMEs should deal with a strategic management. They should have a strategy that would adapt to the current situation and future developments as quickly as possible. When designing the strategy, it is important for the managers to detect new opportunities as soon as possible and to be aware of crises that can spoil these opportunities and threaten the functioning of the organization.

The conclusion has been confirmed by other authors. Smallman (1996) notes, that there is a need for managers to move from a current dominant reactive paradigm to a proactive, holistic approach to dealing with chaos and change. Proactive planning through the use of strategic planning and issues management will help reduce risk, 
time wastage, and poor resource management and reduce the impacts of those that do arise (that notes Heath, 1998 and Thompson and Martin, 2010).

A manager should be able to respond flexibly to the changing external and internal conditions. This requires a systematic approach to analyze the environment and the collection and evaluation of strategically important information that will enable a manager to design a successful strategy and also to anticipate crises better. However, crisis managers need to attribute greater importance than the mean value of 3.4 for all the SMEs in the sample. The best crisis managers also know what changes are needed in corporate governance, organizational culture, and information technology (that confirms Lerminger, 2012). The understanding and subsequent management of such incidents can be vastly improved through the extension and application of crisis and disaster management theory and concepts A strategic, holistic and proactive approach to crisis management is required through:

- developing proactive scanning and planning;

- implementing strategies when crises or disasters occur; and,

- evaluating the effectiveness of these strategies to ensure continual refinement of crisis management strategies (the same opinions mentions Ritchie (2004).

However, it is surprising that failed to demonstrate the influence of a strategy to determine the significance of the crisis by the Wilcoxon test. The test confirmed that the organization with a strategy and those that do not have a defined strategy and see the crises as equally important. Enterprises classified by sectors of the national economy into 5 categories reported the same results in 4 categories. Only the enterprises of B1 reported that the a written strategy affects the meaning of the crisis. The enterprises with strategic management in group B see the crises as more important (the average of 3.7 points), which is the greatest value of all the other sectors. This sector (including the financial sector, insurance companies or companies dealing with information technology) strongly depends on changes in the economic and technological environment. In recent years, this sector has been affected a lot by the global economic crisis. Crises are seen by the managers of these organizations as a threat of possible closure of their enterprise. So, they started to manage their enterprise by the principles of strategic management, establish long-term goals and identify possible crisis. And those who manage their enterprise with a written strategy can better perceive any crises. They have been prepared.

Strategic management of crises requires planning and preparation as well as the consideration of events and impacts that managers, victims and stakeholders would rather not think about. It is also important to have a crisis communications plan in place (as confirmed by Springer, 2008, KeownMcMullan, 1997 or Coombs, 2004).

Acknowledgement: This article has been presented with the financial support of the projects: GAJU $79 / 2013 / S$ and GAJU 053/2016/S. 


\title{
УТИЦАЈ СТРАТЕГИЈА НА ПРОЦЕНУ УТИЦАЈА КРИЗЕ ИЗ УГЛА МЕНАЏЕРА МАЛИХ И СРЕДЫИХ ПОРЕДУЗЕһА
}

\author{
Jaroslav Vrchota, Petr Rehor
}

\begin{abstract}
Извод
Мала и средња предузећа играју значајну улогу у економији Европе, као извор предузетничких вештина, иновације и као генератор нових радних места. Стратегијски менаџмент је од виталног значаја за дугорочну конкурентност ових организација, али је можда и значајнији код суочавања са кризним ситуацијама. Предузећа која имају функцију стратегијског менаџмента су у стању да анализирају своју будућност и њихови менаџери су у стању да унапред препознају надолазеће изазове, те су самим тиме много боље припремњени да реагују на њих. Криза се, на тај начин, може разматрати као феномен који се јавља често а не као ретко заступљена појава. Из тог разлога је од суштинског значаја да пословање рефлектује аспекте и утицај кризе у корпоративној стратегији и да менаџери уче да управљају кризом ефективно.

Овај рад се бави парцијалним истраживањем менаџмента малих и средњих предузећа у Чешкој Републици. Фокус је на дефинисању стратегије од стране менаџера ових организација и на процени значаја кризе. Установљено је да тек $25 \%$ компанија имају формулисану стратегију даљих праваца пословања организације. Ипак, криза се јавља у свим организацијама, уз варијацију нивоа и интензитета. Значај кризе је процењена од менаџера са средњом оценом од 3.4 (на скали где је највиша оцена била 5). Циљ овог чланка је и процена значаја кризе, из угла менаџера, у стратегијски вођеним организацијама, структурираних према областима привреде. За примарно сакупљање података, коришчена је метода упитника.
\end{abstract}

Кључне речи: Стратегија, криза, менаџмент, МСП, област националне економије.

\section{References}

Ambrosini, V., \& Bowman, C. (2009). What are dynamic capabilities and are they a useful construct in strategic management? International Journal of Management Reviews, 11 (1), 29-49.

Andrews, K.R. (1971). The Concept of Corporate Strategy. New York: Dow JonesIrwin.

Booth, S.A. (2015). Crisis management strategy: competition and change in modern enterprises. Boston, USA: Routledge.

Budíková, M., \& Králová, M. (2010).
Guide to basic statistical methods. Praha: Grada.

Coomgs, W.T. (2004). Impact of past crises on current crisis communication. Journal of Business Communication, 41, 265-289.

Deros, B.M., Yusof, S.M., \& Salleh, M.A. (2006). A benchmarking implementation Framework for automotive manufacturing SMEs. Benchmarking International Journal, 13, 396-430.

European Commission (2008). Putting Small Businesses First: Europe is Good for SMEs, SMEs are Good for Europe. 
Luxembourg: European Commission Repronis.

Publications Office.

Faulkner, B. (2001). Towards a framework for tourism disaster management. Tourism Management, 22(2), 135-147.

Fialova, H., \& Fiala, J. (2006). Small Economic Dictionary with the interpretation of terms in Czech and English. Prague, Czech Republic: A plus.

Floyd, D., \& McManus, J. (2005). The role of SMEs in improving the competitive position of the European Union. European Business Review, 17, 144-50.

Freeman, R.E. (2010). Strategic management: A Stakeholder approach. Cambridge, UK: Cambridge university press.

Freund, R. J., Wilson, W., J. (2010). Statistical methods. Prague, Czech Republic: Academic Press.

Friedrich, V., Majovska, R., (2010). Selection of economic statistics. Prague, Czech Republic: Wolters Kluwer.

Gonzales-Herrero, A. \& Pratt, C. (1998). Marketing crises in tourism: Communication strategies in the United States and Spain. Public Relations Review, 24 (1), 83-97.

Heath, R. (1998). Crisis management for managers and executives. London, UK: Financial Times Management.

Johnson, G., Scholes, K. (1993). Exploring coporate strategy. Oxford, UK: Butterworth-Heinemann.

Kash, T.J., \& Darling, J. (1998). Crisis management: Prevention, diagnosis and intervention. Leadership \& Organization Development Journal, 19(4), 179-186.

Keown-McMullan, J. (1997). Crisis: When does a molehill become a mountain? Disaster Prevention and Management, 6(1), 4-10.

Lednicky, V. (2006). Strategic management. Ostrava, Czech Republic:

Lee, Y.F., \& Harrald, J.R. (1999). Critical issue for business area impact analysis in business crisis management: Analytical capability. Disaster Prevention and Management, 8(3), 184-189.

Lerbinger, O. (2012). The crisis manager. Abingdon, UK: Routledge.

MPO. Report on SME Development and support in 2014. Cit. online: http://www.mpo.cz/dokument164106.html

OECD, Eurostat indicators on High-tech industry and Knowledge - intensive services. Annex 3 - High-tech aggregation by NACE Rev. $2 . \quad$ Cit. online: http://ec.europa.eu/eurostat/cache/metadata/ Annexes/htec_esms_an3.pdf

Porter, M.E. (1996). What is Strategy? Harvard Business Review, November/December 1996, 61-78.

Rais, R. (2007). Specifics of Crisis Management. Ostrava, Czech Republic: Key Publishing.

Ritchie, B.W. (2004). Chaos, crises and disasters: a strategic approach to crisis management in the tourism industry. Tourism management, 25(6), 669-683.

Řehoř, P. (2016). Change management. Ceske Budejovice, Czech Republic: EF JCU.

Řehoř, P. (2013). Municipal management strategies of regional development and quantification the position of regions. Journal of Central European Agricultere, 14(3), 197-208.

Rehoř, P. (2015). Changes in the strategic management of municipal development in Czech Republic. International Journal of Humanities social sciences and education, 2(6), 29-35.

Smallman, C. (1996). Challenging the orthodoxy in risk management. Safety Science, 22 (1-3), 245-262.

Springer, C. G. (2008). Strategic 
management of crises. PA Times, 31(7). Cit. $\begin{array}{lllllll} & \mathrm{n} & \mathrm{n} & \mathrm{i} & \mathrm{i} & \mathrm{n} & \mathrm{e}\end{array}$ http://digitalscholarship.unlv.edu/sea_fac_ar ticles/333

Thompson, J.L., \& Martin, F. (2010). Strategic management. Awareness and change. Nashville, Tennessee, USA: SouthWestern publishing.

Vargo, J., \& Seville, E. Crisis strategic planning for SMEs: finding the silver lining. International Journal of Production Research, 49(18), 5619-5635.

Vodacek, L., \& Vodackova, O. (2009). Modern management in praxe. Prague, Czech Republic: Management Press. 